\title{
R FACTORS IN ENTEROBACTERIACEAE CAUSING URINARY-TRACT INFECTION IN GENERAL PRAC- TICE IN 1962-63 AND 1968-69
}

\author{
Elizabeth J. Shaw, ${ }^{*}$ Rita E. Pursell, $\dagger$ Naomi Datta and \\ W. BRUMFITT $\ddagger$ \\ Department of Bacteriology, Royal Postgraduate Medical School, \\ Ducane Road, London W12 OHS, and \\ Edgware General Hospital, Edgware, Middlesex
}

SINCE the discovery of infectious drug resistance factors ( $R$ factors) in 1959 there has been great interest in their spread and incidence. In Salmonella and Shigella, a marked increase in resistance due to acquisition of $\mathbf{R}$ factors has been well documented (Anderson, 1968; Mitsuhashi, 1969; Davies, Farrant, and Uttley, 1970). The bacteria of the human bowel also carry $\mathbf{R}$ factors (Datta, 1969, Datta et al., 1971) and represent a large pool of resistant organisms capable of causing infection in man. Non-enteropathogenic $R+$ bacteria are known to cause infections acquired within hospitals (Smith and Armour, 1966; Gardner and Smith, 1969; Anderson, Datta, and Shaw, 1972) but little is known of the incidence of infection with these organisms in the general community. Infections with organisms of these genera outside hospital are predominently of the urinary tract, so the incidence of resistant organisms causing urinary infections was studied.

Brumfitt et al. (1971) reported resistance to one or more antibiotics in 7 of 37 (19 per cent.) of Escherichia coli causing urinary-tract infection in general practice. In the present study those figures are extended.

\section{MATERIALS AND METHODS}

Patients who had acquired urinary-tract infections outside hospital were studied at the Edgware General Hospital (Grüneberg, Leigh and Brumfitt, 1968). Cultures from 50 of the patients seen in 1962-63 and another 50 in 1968-69 were randomly selected for this study. The cultures had been stored either in stabs or slopes and were all examined together in 1970. The minimum inhibitory concentration (MIC) of the following drugs was determined: ampicillin (A), streptomycin (S), tetracycline (T), chloramphenicol (C), kanamycin (K), sulphafurazole (Su), nalidixic acid (Nal), and trimethoprim (Tr), by incorporating two-fold dilutions of the appropriate drug in Nutrient Agar plates (Oxoid No. 2) containing 4 per cent. lysed horse blood. Plates were inoculated with a multiple-point inoculator, the two inocula for each culture being $10^{5}$ and 10 organisms. Plates were incubated overnight and the lowest concentration of drug which inhibited growth was recorded as the MIC. A control sensitive $E$. coli $\mathrm{K} 12$ strain was included in all tests. Results were reproducible on repetition with no more than two-fold variation. Except for sulphafurazole, the MIC for sensitive strains did

Received 15 Dec. 1972 ; accepted 30 Jan. 1973.

* Present address: Department of Bacteriology, St Bartholomew's Hospital, London E.C.1. † Present address: Department of Bacteriology, University of Southampton, Southampton. $\mp$ Present address: Department of Bacteriology, Royal Free Hospital, London W.C.1.

J. MED. MICROBJoL,-VOL. 6 (1973) 
not differ by more than two-fold from the control culture. Resistant strains were 8-128 times more resistant. For sulphafurazole, the control $E$. coli was inhibited by $8 \mu \mathrm{g}$ per ml. However, a strain was recorded as resistant only if it grew in the presence of $100 \mu \mathrm{g} \mathrm{per} \mathrm{ml.}$

Cultures were tested for transfer of drug resistance to $E$. coli $\mathrm{K} 12$ in mixed culture (for methods see Datta, 1968). If resistance was not transferred directly, an attempt was made to "mobilise" it by introducing a de-repressed R factor (Anderson 1965; Meynell and Datta, 1967).

\section{RESULTS}

The results are shown in tables I and II. All organisms studied were E. coli. By the use of an exact test, a statistically significant increase $(p<0.05)$ was

TABLE I

Resistance of Escherichia coli isolates to antibiotics

\begin{tabular}{|c|c|c|c|c|c|c|c|c|c|}
\hline \multirow{2}{*}{ Year } & \multirow{2}{*}{$\begin{array}{l}\text { Total } \\
\text { number of } \\
\text { isolates }\end{array}$} & \multicolumn{8}{|c|}{ No. (and percentage) of isolates resistant to } \\
\hline & & $A^{*}$ & $\mathbf{S}$ & $\mathrm{T}$ & $\mathrm{C}$ & $\mathbf{K}$ & $\mathrm{Su}$ & $\mathrm{Nal}$ & $\operatorname{Tr}$ \\
\hline $\begin{array}{l}1962-63 \\
1968-69\end{array}$ & $\begin{array}{l}50 \\
50\end{array}$ & $\begin{array}{c}0 \\
1(2)\end{array}$ & $\begin{array}{c}0 \\
4(8)\end{array}$ & $\begin{array}{l}3(6) \\
5(10)\end{array}$ & $\begin{array}{l}\mathbf{0} \\
\mathbf{0}\end{array}$ & $\begin{array}{l}0 \\
0\end{array}$ & $\stackrel{0}{8(16)}$ & $\begin{array}{l}0 \\
0\end{array}$ & $\begin{array}{l}0 \\
0\end{array}$ \\
\hline
\end{tabular}

* See Methods for key.

TABLE II

Resistance patterns of $E$. coli from patients with urinary-tract infections

\begin{tabular}{l|cc}
\hline \multicolumn{1}{|c|}{ Resistance pattern } & $\begin{array}{c}\text { Number of isolates with } \\
\text { the stated resistance } \\
\text { pattern in years }\end{array}$ \\
\cline { 2 - 2 } $1962-63$ & $1968-69$ \\
\hline $\begin{array}{l}\text { Fully sensitive } \\
\text { Resistant to Su* }\end{array}$ & 47 & 40 \\
Resistant to T & $\ldots$ & 2 \\
Resistant to SSu & 3 & 2 \\
Resistant to TSu & $\ldots$ & 2 \\
\hline Resistant to any agent & $\ldots$ & 1 \\
\hline
\end{tabular}

* See Methods for key.

detected in the incidence of resistance between the two series. All three of the tetracycline-resistant strains isolated in the 1962-63 series were able to transfer resistance directly to a recipient $E$. coli $\mathrm{K} 12$ strain. Of the second series, three strains transferred resistance (ASTSu, TSu and $\mathrm{Su}$ ); in three strains the plasmid was mobilised (SSu, TSu, and T) and in four strains transfer could not be demonstrated $(\mathrm{Su}, \mathrm{SSu} \times 2$, and $\mathrm{T})$. 


\section{Discussion}

These small series show a definite but small increase in R-factor-mediated resistance in $E$. coli causing infections in the general community; but it was less than that seen in shigellae and salmonellae (Anderson, 1968; Davies et al.).

Studies on the changing pattern of antibiotic resistance in $E$. coli outside hospitals are few. In two series of observations made in different parts of this country (Essex: Robertson, 1971; Bristol: Gillespie et al., 1971), the same general but slight trend of increasing resistance was seen. Other surveys have usually investigated only resistance to one or two drugs and these have shown variable changes in the frequency of resistance (Brooks, 1968; Brown et al., 1968; Williams and Leigh, 1966).

It is not possible to be sure that $R$ factors were not lost from the 1962-63 cultures during storage. Of 42 cultures of known $\mathrm{R}+E$. coli that had been stored in conditions similar to the urinary strains for $6 \mathrm{yr}, \mathrm{R}$ factors had been lost from six. A rate of loss of this order from the 1962-63 cultures would not negate the difference between the two series. Anderson (1968) also noted that $\mathrm{R}$ factors in $E$. coli were stable in vitro when stored in the original bacterial host.

It therefore appears that there is a general but not marked increase in infectious drug resistance in E. coli causing infection outside hospital in various parts of England.

\section{SUMMARY}

Antibiotic-resistance patterns of Escherichia coli causing urinary-tract infections contracted outside hospital were studied in 1962-63 and 1968-69. There was a slight but statistically significant increase in resistance over this period. The resistance was, in most instances, transferable.

One of us (E.J.S.) was supported by a grant from Beecham Research Laboratories.

\section{REFERENCES}

ANDERson, E. S. 1965. A rapid screening test for transfer factors in drug-sensitive Enterobacteriaceae. Nature, Lond., 214, 885.

ANDERSON, E. S. 1968. The ecology of transferable drug resistance in the enterobacteria. A. Rev. Microbiol., 22, 131.

Anderson, F. M., Datta, Naomi, AND Shaw, Elizabeth J. 1972. R factors in hospital infection. Br. Med.J., 3, 82.

Brooks, D. 1968. Urinary tract infection. Br. Med. J., 3, 745.

Brown, P. C. C., Donaghy, M. C., Dootson, P. H., Maclaren, D. M., and Trtcombe, D. H. N. 1968. Urinary tract infection. Br. Med. J., 4, 190.

Brumfitt, W., Faiers, Mary C., Reeves, D. S., aNd Datta, NaOmi 1971. Antibiotic resistant Escherichia coli causing urinary-tract infection in general practice: relation to faecal flora. Lancet Lond., 1, 315.

DATTA, NAOMI 1968. Acquisition of antibiotic resistance by bacteria. In Recent advances in clinical pathology, edited by S. C. Dyke, London, p. 43.

DATTA, NAOMI 1969. Drug resistance and $R$ factors in the bowel bacteria of London patients before and after admission to hospital. Br. Med. J., 2, 407.

DatTa, NaOmi, Faiers, Mary C., Reeves, D. S., BrumfitT, W., Ørskov, F., and Ørskov, IDA 1971. $\mathrm{R}$ factors in Escherichia coli in faeces after oral chemotherapy in general practice. Lancet, Lond., 1, 312. 
Davies, J., FARrant, W. N., AND UTtLeY, ANN 1970. Antibiotic resistance of Shigella sonnei. Lancet, Lond., 2, 1157.

GARDNER, P., AND SmITH, D. H. 1969. Studies on the epidemiology of resistance (R) factors. I. Analysis of Klebsiella isolates in a general hospital. II. A prospective study of $\mathrm{R}$ factor transfer in the host. Ann. Intern. Med., 71, 1.

Gulespie, W. A., Lee, P. A., Linton, K. B., AND Rowland, A. J. 1971. Antibiotic resistance of coliform bacilli in urinary infection acquired by women outside hospital. A 12year survey. Lancet, Lond., $2,675$.

Grüneberg, R. N., Leigh, D. A., AND BrUmfrtr, W. 1968. Escherichia coli seroypes in urinary tract infections: studies in domiciliary, antenatal and hospital practice. In Urinary tract infection, Proceedings of the First National Symposium, edited by F. O'Grady and W. Brumfitt, London, p. 68.

Meynell, Elinor, AND DatTA, NaOmi 1967. Mutant drug resistant factors of high transmissibility. Nature, Lond., 214, 885.

MrtshuHAShi, S. 1969. The R factors. J. Infect. Dis., 119, 89.

ROBERTSON, M. H. 1971. A 6-year survey of resistance patterns of urinary tract pathogens in general practice. Post-grad. Med. J., 47, 111.

Smith, D. H., AND ARmour, S. E. 1966. Transferable R factors in enteric bacteria causing infection of the genitourinary tract. Lancet, Lond., $2,15$.

Williams, J. D., AND Leigh, D. A. 1966. The sensitivity of organisms to sulphonamides. Br. J. Clin. Prac., 20, 177. 